\title{
Deoxyribonucleic Acid Metabolism and Nuclear Division during Spore Germination in Fusarium oxysporum
}

\author{
By LALITHA KUMARI, J. R. DECALLONNE AND J. A. MEYER \\ Laboratoire de Phytopathologie et de Mycologie générale, \\ Université Catholique de Louvain, 3030 Heverlee, Belgium
}

(Received I6 September I974; revised I7 January 1975)

SUMMARY

\begin{abstract}
Ungerminated microconidia of Fusarium oxysporum have a mean cell DNA content of $0.134 \times 10^{-12} \mathrm{~g} /$ cell with a guanine-plus-cytosine composition ( $\left.\% \mathrm{GC}\right)$ of $50.75 \%$. During germination, the first dry weight increase of the spore population was detected after $3 \mathrm{~h}$ incubation and the first germ tube appeared after $4 \mathrm{~h}$. The total DNA of the culture sharply increased after $5 \mathrm{~h}$, followed by a pause at $6 \mathrm{~h}$. At this time the DNA content per nucleus was maximal and the first nuclear divisions were detected. Pauses in the rise of total DNA of the culture and in the $\left[{ }^{14} \mathrm{C}\right]$ adenine incorporation pattern suggest that there is partial synchrony in DNA synthesis at the beginning of incubation. This is also supported by the fact that until $8 \mathrm{~h}$, only hyphae with I, 2 and 4 nuclei were observed. $\left[{ }^{14} \mathrm{C}\right]$ adenine incorporation into DNA averaged $2.68 \%$ of the total taken up in $\mathrm{Io}$ h incubation.
\end{abstract}

\section{INTRODUCTION}

Despite a number of recent studies on the physiological features and synthesis of the main constitutive macromolecules associated with fungal spore germination, relatively little attention has been focused on the relationships between DNA synthesis and the other metabolic modifications occurring during spore germination (Gottlieb \& Tripathi, 1968; Hollomon, 1970; Cochrane, Rado \& Cochrane, 1971; Bainbridge, I971). Because of the number of new systemic fungicides that have been reported or suggested to act as inhibitors of DNA synthesis or as antimitotic compounds (Sisler, I968; Van der Kerk, 1969; Sijpesteijn, 1970; Erwin, 1973), it appears useful to study DNA structure and metabolism in filamentous fungi. This study of Fusarium oxysporum microconidia reports the relationships between DNA synthesis and germination, dry weight increase, total DNA of the population, DNA composition, and nuclear behaviour.

\section{METHODS}

Organism and cultivation. Fusarium oxysporum f.sp. melonis strain MI5D, maintained in soil stock cultures, was used to inoculate agar slants, and then $100 \mathrm{ml}$ portions of liquid growth medium (glucose, $20 \mathrm{~g}$; asparagine, $\mathrm{I} \cdot 5 \mathrm{~g} ; \mathrm{K}_{2} \mathrm{HPO}_{4}, \mathrm{I} \cdot 0 \mathrm{~g} ; \mathrm{MgSO}_{4} \cdot 7 \mathrm{H}_{2} \mathrm{O}, 0.5 \mathrm{~g}$; $\mathrm{FeCl}_{3}, \mathrm{O} \cdot \mathrm{I} \mathrm{g}$; yeast extract, $\mathrm{I} \cdot 0 \mathrm{~g} ; \mathrm{H}_{2} \mathrm{O}$ to $\mathrm{I} 1$ ) in $500 \mathrm{ml}$ conical flasks incubated on a rotary shaker at $90 \mathrm{rev} . / \mathrm{min}$ for 3 days at $26{ }^{\circ} \mathrm{C}$. The microconidia produced by these pre-cultures were isolated by sterile filtration through cheese-cloth and used to inoculate fresh medium $(100 \mathrm{ml})$ to an initial concentration of $0.5 \times 10^{6}$ conidia $/ \mathrm{ml}$. After 3 days incubation, 
microconidia were recovered by filtration and used as starting material for further studies. For some assays the whole fungal material produced after 3 days was used.

Estimation of DNA. The isolation of a DNA-containing fraction from the fungal material was carried out by using a modified Schneider's procedure (Munro \& Fleck, 1966). Each sample collected was frozen quickly in an ethanol-dry ice mixture and stored at $-25^{\circ} \mathrm{C}$. The samples for DNA isolation were thawed and centrifuged at $4{ }^{\circ} \mathrm{C}$ at $15000 \mathrm{~g}$ for $20 \mathrm{~min}$ to separate the fungal material, which was then subjected to a 60 min cold $5 \%(\mathrm{v} / \mathrm{v})$ TCA treatment. Another centrifugation was carried out at $15000 \mathrm{~g}$ for $20 \mathrm{~min}$, after which the DNA contained in the precipitated material was hydrolysed by a I M-perchloric acid (PCA) treatment at $70{ }^{\circ} \mathrm{C}$ for $20 \mathrm{~min}$. The suspension was centrifuged under the same conditions and the precipitate treated a second time with I M-PCA at $70{ }^{\circ} \mathrm{C}$ for $20 \mathrm{~min}$. After a last centrifugation at $15000 \mathrm{~g}$ for $20 \mathrm{~min}$ the two supernatants were pooled and used for DNA estimation. Both TCA and PCA treatments were carried out with a wet weight to volume ratio between the fungal material and the acidic solution of $I: 9$. The residue left after the last centrifugation was taken for dry weight determination. DNA was estimated by Burton's improved method (Giles \& Meyers, 1965), further modified here by excluding the acetaldehyde reagent because the addition of this compound produced turbidity and a green colour even when freshly prepared. The modified reaction mixture consisted of $2 \mathrm{ml}$ hydrolysate obtained after PCA treatment and $2 \mathrm{ml}$ of freshly prepared $4 \%$ diphenylamine dissolved in glacial acetic acid. After $16 \mathrm{~h}$ at $30{ }^{\circ} \mathrm{C}$, the resulting blue colour was measured from the difference in the extinctions at 595 and $700 \mathrm{~nm}$. The DNA concentration of the sample was calculated from a calibration curve, with salmon-testis DNA as standard.

Dry weight determination. For dry weight determinations of untreated conidial suspensions, samples were filtered through Gelman glass-fibre filters. The samples were dried at $75^{\circ} \mathrm{C}$ for $2 \mathrm{~h}$ under forced air circulation before determining the dry weight. The dry weight of the DNA-extracted samples was determined as above on the residue left after the second PCA hydrolysis, with a correction applied for loss due to the extraction procedure.

Extraction of undegraded DNA. The procedure of Marmur (I96I) was applied, with some modifications of the cell-rupture method and using $20 \mathrm{~g}$ (wet wt) of fungal material obtained from 3-day-old cultures. The mycelial mats were cut into small pieces and washed twice with $120 \mathrm{ml}$ acetone and once with $120 \mathrm{ml}$ ether. The solid material was recovered each time by centrifugation at $15000 \mathrm{~g}$ for $20 \mathrm{~min}$. Some solid $\mathrm{CO}_{2}$ was layered into a prechilled mortar and the residual fungal material was mixed with it for rapid freezing; $10 \mathrm{ml}$ of $0 . \mathrm{I} \mathrm{M}$-EDTA-0.I $5 \mathrm{M}-\mathrm{NaCl}$ solution, $\mathrm{pH} 8.0$ (saline EDTA) and I ml of $20 \%$ sodium dodecyl sulphate (SDS) solution were added dropwise before grinding the mixture for Io min. The homogenate was then mixed with $\mathrm{I} 20 \mathrm{ml}$ saline EDTA and $\mathrm{I} 2 \mathrm{ml}$ SDS solution and allowed to dissolve before being centrifuged at $15000 \mathrm{~g}$ for $20 \mathrm{~min}$. The supernatant was collected into a separate beaker and the residue ground a second time under the same conditions as before. The ground mixture was added to the supernatant collected earlier, without further centrifugation. The whole procedure was carried out at $4{ }^{\circ} \mathrm{C}$. Marmur's procedure was applied without further modifications and the DNA strands recovered were dissolved in $10 \mathrm{ml}$ of a $0.15 \mathrm{M}-\mathrm{NaCl}-0.015 \mathrm{M}$-trisodium citrate solution, $\mathrm{pH} 7.0$ (standard saline citrate, $\mathrm{SSC}$ solution).

DNA structural analysis. Samples of undegraded DNA in SSC solution were precipitated by cold ethanol and dissolved in 0.1 M-acetic acid $\mathrm{pH} 3.0$. Extinctions were measured at 260 and $280 \mathrm{~nm}$ and the molar percentage of guanine plus cytosine $(\% \mathrm{GC})$ calculated according to Marmur \& Doty (I962). Thermal denaturation analyses were also conducted 
with DNA dissolved into SSC solution, using a Beckman Acta C III spectrophotometer equipped with a variable temperature cell. The median denaturation temperature $\left(T_{\mathrm{m}}\right)$ was determined according to the procedure of Krieg \& Lockhart (1970).

Labelled DNA precursor uptake and incorporation studies. Labelling experiments were carried out using adenine-8-[14 $\mathrm{C}]$ chlorhydrate (specific activity $53.5 \mathrm{mCi} / \mathrm{mm}$ ) to follow the rate of DNA synthesis of conidia during their germination. Adenine- $8-\left[{ }^{14} \mathrm{C}\right]$ chlorhydrate incorporated satisfactorily into the DNA of $F$. oxysporum conidia, while more specific radioactive DNA precursors $\left(\left[2-{ }^{14} \mathrm{C}\right]\right.$ thymidine and $\left[2-{ }^{14} \mathrm{C}\right]$ thymine $)$ were only poorly incorporated into the DNA of the conidia. This is in agreement with Grivell \& Jackson's ( 1968) data on the lack of thymidine kinase in Neurospora crassa. The initial conidial populations used for labelling consisted essentially of ungerminated conidia $(99 \%)$ recovered from 3-day-old cultures. The radioactive isotope was dissolved in methanol so that the final methanol concentration in the incubation medium did not exceed $0.5 \%$ $(\mathrm{v} / \mathrm{v})$. The incubations were carried out with $2 \mu \mathrm{Ci} / 100 \mathrm{ml}$ medium, the final concentration of adenine being adjusted to $2 \mu \mathrm{g} / \mathrm{ml}\left(\mathrm{I} \cdot \mathrm{I} \times \mathrm{IO}^{-5} \mathrm{M}\right)$ by adding unlabelled adenine. For pulse-labelling experiments $4 \mu \mathrm{Ci} / 100 \mathrm{ml}$ were used, with a final unchanged molarity for adenine. Both the stage of conidial development at which the radioisotope was added and the labelling that was applied varied with each type of experiment. The labelling of the conidia was stopped by adding formaldehyde solution to the suspensions to a final concentration of $5 \%(\mathrm{v} / \mathrm{v})$. Samples were then removed and filtered through glass-fibre filters to isolate the conidia. The samples were washed with cold distilled water until no more radioactivity was found in the filtrate. Filters with fixed conidia were dried for $10 \mathrm{~min}$ under an infrared lamp, added to Io ml of Bray's (I960) mixture, and counted in a Packard Tri-carb model 2420 liquid scintillation spectrometer for $\left[{ }^{14} \mathrm{C}\right]$ adenine uptake. The counting efficiency calculated by the channels ratio method ranged between 45 and $55 \%$. To determine the rate of incorporation of $\left[{ }^{14} \mathrm{C}\right]$ adenine into the DNA of the conidia, the procedure used for the DNA colorimetric estimation was further modified. The conidia isolated on glass-fibre filters were washed with water to remove the residual radioactivity and the filters were then immersed in $15 \mathrm{ml}$ of cold $5 \%$ TCA in a set of Petri dishes maintained at $4{ }^{\circ} \mathrm{C}$ for $60 \mathrm{~min}$. Each sample was then placed back on the filtration system and the cold TCA-soluble radioactivity was removed by washing with $20 \mathrm{ml}$ of cold distilled water. The samples were subsequently treated with $15 \mathrm{ml}$ of I M-NaOH for $2 \mathrm{~h}$ at $37^{\circ} \mathrm{C}$, as for the TCA treatment, before being washed free of hydrolysed RNA with $30 \mathrm{ml}$ cold distilled water. The residues left on the filters were dried and their radioactivity determined by the same procedure as for uptake measurements. The $\left[{ }^{14} \mathrm{C}\right]$ adenine radioactivity recovered in this fraction was considered as representative of the incorporation of the precursor into the fungal DNA.

Nuclear staining. The nuclei were stained with $\mathrm{HCl}$-Giemsa (Aist \& Wilson, 1965). Samples $(0.1 \mathrm{ml})$ of conidial suspension were spread on glass slides with an adhesive solution and dried before being subjected to the following sequential transfers: Carnoy solution, $30 \mathrm{~min} ; 94 \%$ alcohol, I $5 \mathrm{~min} ; 50 \%$ alcohol, $15 \mathrm{~min}$; I $\mathrm{M}-\mathrm{HCl}$, Io min; I $\mathrm{M}-\mathrm{HCl}$ at $60{ }^{\circ} \mathrm{C}$, Io $\mathrm{min}$; distilled water, I $5 \mathrm{~min} ; 0.1 \mathrm{M}$-phosphate buffer $\mathrm{pH} 7.0$ and water $(50: 50$, $\mathrm{v} / \mathrm{v}$ ), Io min; o.I M-phosphate buffer $\mathrm{pH} 7.0$, I0 min; Giemsa staining solution ( $5 \mathrm{ml}$ Azur eosin methylene blue and $65 \mathrm{ml} \mathrm{O.I} \mathrm{M-phosphate} \mathrm{buffer,} \mathrm{pH} 7 \cdot 0$ ), $15 \mathrm{~min}$. Final washing was performed in phosphate buffer $\mathrm{pH} 7^{\circ} \mathrm{O}$. 


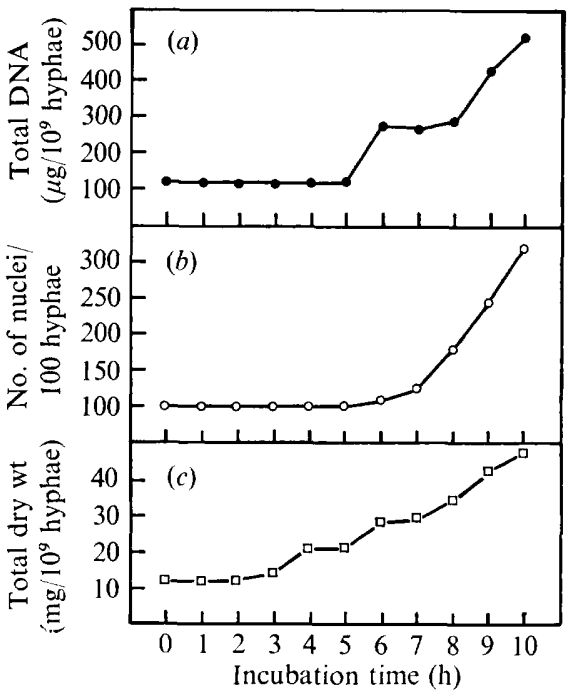

Fig. I

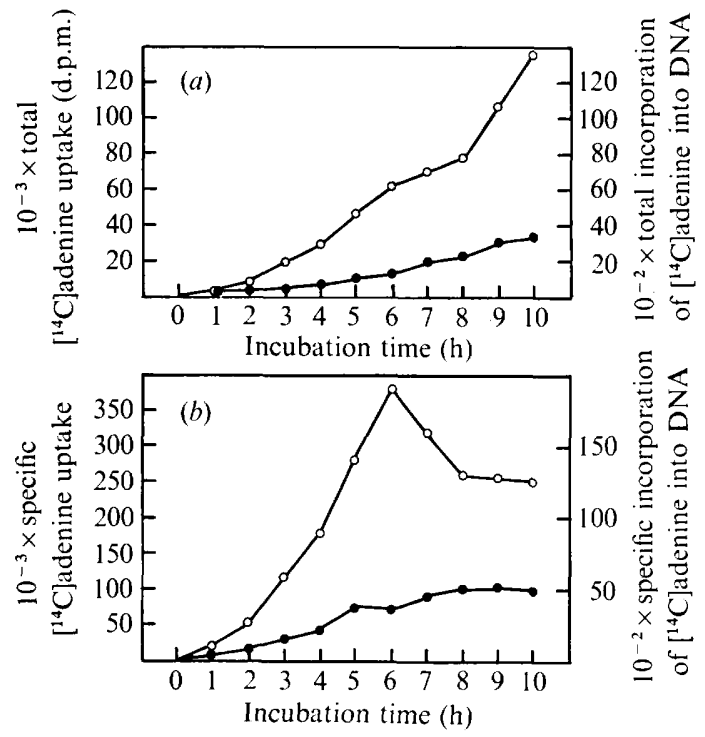

Fig. 2

Fig. I. Total DNA $(a)$, number of nuclei $(b)$, and total dry weight $(c)$ for a population of germinating $F$. oxysporum conidia. The total DNA (O) and the dry weight values $(\square)$ were calculated for a population of $10^{9}$. The number of nuclei $(O)$ refers to 100 hyphae.

Fig. 2. (a) Total and (b) specific uptake and incorporation of $\left[{ }^{14} \mathrm{C}\right]$ adenine into germinating conidia of $F$. oxysporum. The radioactive precursor was introduced into the medium $(2 \mu \mathrm{Ci} / \mathrm{I} 00 \mathrm{ml})$ at time zero and the labelling was carried out continuously for $10 \mathrm{~h}$, and measured at intervals. The initial total adenine concentration was adjusted to $2 \cdot 0 \mu \mathrm{g} / \mathrm{ml}\left(\mathrm{I} \cdot \mathrm{I} \times 1 \mathrm{IO}^{-6} \mathrm{M}\right)$ by adding the unlabelled compound. (a) The total $\left[{ }^{14} \mathrm{C}\right]$ adenine cellular uptake $(O)$ and the incorporation of the precursor into the DNA fraction (O) were calculated as disintegrations/min (d.p.m.) recovered at each incubation time from an initial population of $10^{9}$ conidia. (b) The specific values were expressed as d.p.m. $\left[{ }^{14} \mathrm{C}\right]$ adenine taken up/I00 $\mathrm{mg}$ dry weight $(\mathrm{O})$, and d.p.m. incorporated into DNA (•) mg DNA.

\section{RESULTS}

\section{DNA content of ungerminated conidia}

Repeated determinations on ungerminated microconidia gave an average DNA content of $I \cdot I 4 \%(W / v)$ on a dry weight basis and a mean dry weight of $I I \cdot 8 \mathrm{mg}$ for a $10^{9}$ conidium population. The absolute DNA content was calculated to be $0.134 \times 10^{-12} \mathrm{~g} /$ ungerminated cell.

\section{DNA structural characterization}

An average value of $49.45 \%$ (S.D. $\pm 2 \cdot 76$ ) was found for the $\% \mathrm{GC}$ by using De Ley's (I967) equation: \% GC $=\mathrm{I} 68 \cdot 6-87 \cdot 4\left(E_{260} / E_{289}\right)$. It was found impossible to reduce the standard deviation calculated for the $\% \mathrm{GC}$, which resulted from a high variability in the ratio of extinctions. This supported De Ley's conclusions that this procedure can only be used for a quick approximation of DNA composition and to obtain a first estimation of the transition midpoint temperature $\left(T_{\mathrm{m}}\right)$. Therefore extracted native DNA was further analysed by thermal denaturation, using the hyperchromic rise at $260 \mathrm{~nm}$ and Marmur \& Doty's (I962) equation: $T_{\mathrm{m}}=69 \cdot 3+0.4 \mathrm{I}(\% \mathrm{GC})$. An average value of $50.75 \%$ (S.D. \pm 0.30 ) was calculated for the GC content of the $F$. oxysporum DNA, which corresponded to a mean $T_{\mathrm{m}}$ value of $90^{\circ} \mathrm{II}{ }^{\circ} \mathrm{C}$ after proper corrections were made for water expansion. The same 
Table I. Dry weight, germination, nuclear distribution, and DNA per nucleus during spore germination

Each estimate of the number of nuclei was done on 300 hyphae.

\begin{tabular}{|c|c|c|c|c|c|c|c|c|c|c|c|c|}
\hline \multirow{2}{*}{$\begin{array}{c}\text { Time } \\
\text { (h) }\end{array}$} & \multirow{2}{*}{$\begin{array}{c}\text { Dry weight } \\
\text { (mg/10 } \\
\text { spores) }\end{array}$} & \multirow{2}{*}{$\begin{array}{c}\text { Germ-tube } \\
\text { emergence } \\
(\%)\end{array}$} & \multirow{2}{*}{$\begin{array}{c}\text { Mean no } \\
\text { nuclei/ } \\
\text { spore }\end{array}$} & \multicolumn{7}{|c|}{$\begin{array}{c}\text { Percentage hyphae with the given no. of } \\
\text { nuclei/hyphae: }\end{array}$} & \multirow{2}{*}{\multicolumn{2}{|c|}{$\begin{array}{r}\text { Relative } \\
\text { DNA } / \\
8 \text { nucleus }\end{array}$}} \\
\hline & & & & I & 2 & 3 & 4 & 5 & 6 & 7 & & \\
\hline 0 & II $\cdot 8$ & - & I & 100 & - & - & - & - & - & - & -. & I \\
\hline I & I I $\cdot 8$ & - & - & - & $\ldots$ & - & - & - & - & - & - & I \\
\hline 2 & $1 \mathrm{I} \cdot 8$ & - & - & - & - & - & - & - & - & - & - & I \\
\hline 3 & $13 \cdot 2$ & - & - & - & - & - & - & - & - & - & $\ldots$ & I.07 \\
\hline 4 & $20 \cdot 7$ & 17 & - & $=$ & - & - & - & - & - & - & - & $I \cdot 2 I$ \\
\hline 5 & $21 \cdot 7$ & 33 & - & $\ldots$ & - & - & - & - & - & - & - & $\mathrm{I} \cdot 17$ \\
\hline 6 & $28 \cdot 7$ & 74 & $\mathrm{I} \cdot 08$ & 94 & 5 & - & I & - & - & - & - & $2 \cdot 06$ \\
\hline 7 & $30 \cdot 2$ & $9 i$ & $I \cdot 26$ & 78 & 20 & - & 2 & - & - & - & $\cdots$ & I. 54 \\
\hline 8 & $35 \cdot 2$ & 94 & $1 \cdot 76$ & 44 & 46 & - & 10 & - & - & - & - & $1 \cdot 30$ \\
\hline 9 & $46 \cdot 2$ & 95 & $2 \cdot 47$ & $2 I$ & 46 & 9 & I9 & I & 3 & - & I & $1 \cdot 30$ \\
\hline 10 & $49 \cdot 7$ & 95 & $3 \cdot 43$ & 8 & 25 & 20 & 28 & 7 & 8 & 2 & 2 & $\mathrm{I} \cdot \mathrm{I} 5$ \\
\hline
\end{tabular}

procedure applied to calf-thymus DNA yielded a $4 \mathrm{I} \cdot 70 \% \mathrm{GC}$ value, which is very close to the mean value reported in the literature.

\section{$D N A$ content and nuclear division of a germinating conidial population}

Starting with uninucleate ungerminated conidia, the changes in the total dry weight, total DNA, and total number of nuclei of the population during $\mathrm{I} O \mathrm{~h}$ incubation are given in Fig. I. Using the growth conditions given in Methods, the first dry weight increase of the population was detected at $3 \mathrm{~h}$, while total DNA was found to remain nearly unchanged for $5 \mathrm{~h}$, the first significant increase being observed only during the 6th hour of incubation.

The calculated DNA content ( $\%$ DNA) of the cells was higher for the first few hours of incubation. From a mean initial value of $I \cdot I 4 \%$ for the ungerminated conidia, it fell to an average level of $0.95 \%$ which remained unchanged up to $10 \mathrm{~h}$. The total number of nuclei increased from the 6th hour of incubation at a slow rate, since it had reached a value of only $108 / 100$ conidia at a time when $37.5 \%$ of the total DNA increase had already occurred. This resulted in a progressive increase in the absolute amount of DNA/nucleus (Table 1), which reached a maximum rate at $6 \mathrm{~h}\left(0.276 \times 10^{-12} \mathrm{~g} /\right.$ nucleus $)$. After $10 \mathrm{~h}$ incubation, the total number of nuclei in the population had increased 3.43 -fold, and the average DNA content/nucleus had reached a value $\left(0.155 \times 10^{-12} \mathrm{~g}\right)$ somewhat higher than that of ungerminated conidia, although the $\%$ DNA when calculated on a dry weight basis was less at the end of the incubation period.

\section{Spore germination and nuclear division rate}

The data related to germination and the first nuclear divisions are given in Table $\mathrm{r}$. Germination began after $4 \mathrm{~h}$ of incubation and proceeded rapidly until $8 \mathrm{~h}$. The nuclei remained undivided for at least $5 \mathrm{~h}$ incubation, since the first nuclear divisions were observed only at $6 \mathrm{~h}$. A $50 \%$ germination value for the population occurred at $6.20 \mathrm{~h}$, while a $50 \%$ value for the first nuclear divisions was observed soon after $8 \mathrm{~h}$. By following nuclear distribution at different incubation times, it was found (Table I) that for the first $8 \mathrm{~h}$ only hyphae with I, 2 and 4 nuclei could be observed, and thereafter the nuclear distribution became unbalanced since hyphae with I to 8 nuclei were recovered. 


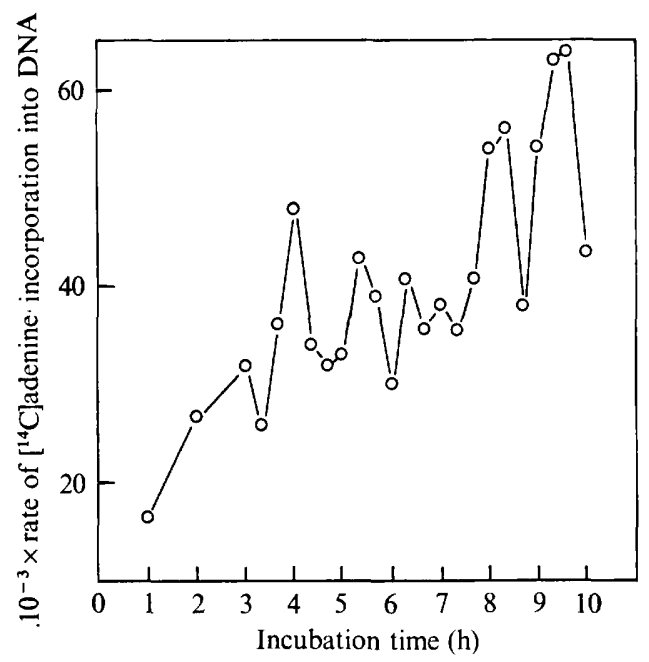

Fig. 3. $\left[{ }^{14} \mathrm{C}\right]$ adenine incorporation rate into the DNA of germinating $F$. oxysporum conidia. The labelling was done in a discontinuous way at $20 \mathrm{~min}$ intervals, the concentration in $\left[{ }^{14} \mathrm{C}\right]$ adenine being adjusted to $0.75 \times 10^{-6} \mathrm{M}$ when each pulse-labelling period started. The incorporation data were expressed as d.p.m. recovered from DNA fractions obtained each time from $10^{9}$ conidia. The other incubation conditions were as for Fig. 2, except that no cold adenine was added.

\section{$\left[{ }^{14} \mathrm{C}\right]$ adenine uptake and incorporation into DNA}

To follow the rate of DNA synthesis during germination of the conidia, two different kinds of $\left[{ }^{14} \mathrm{C}\right]$ adenine labelling experiments were carried out. In the first, the radioactive precursor was introduced in the incubation medium and the growth of ungerminated conidia was allowed to start; labelling continued for $\mathrm{I}$ o $\mathrm{h}$, with intermediate measurements at $60 \mathrm{~min}$ intervals. Fig. 2 shows typical patterns of $\left[{ }^{14} \mathrm{C}\right]$ adenine uptake and incorporation into germinating conidia when the cells were submitted to continuous labelling. The percentage incorporation of label into DNA compared with the uptake of the cell was very low, with an average value of $2.68 \%$. When calculated on a dry weight basis, the specific $\left[{ }^{14} \mathrm{C}\right]$ adenine uptake by the conidia reached a maximum at $6 \mathrm{~h}$ and then decreased sharply; the $\left[{ }^{14} \mathrm{C}\right]$ adenine specific incorporation into DNA, however, increased slowly almost until the end of the incubation. For the second scheme of labelling, $\left[{ }^{14} \mathrm{C}\right]$ adenine was added to the conidial population at $20 \mathrm{~min}$ intervals during the whole $10 \mathrm{~h}$ incubation period. The rates of incorporation of the radioactive precursor are shown in Fig. 3. There was a progressive increase in the extent of incorporation of $\left[{ }^{14} \mathrm{C}\right]$ adenine into DNA as germination and growth proceeded. However, some significant $\left[{ }^{14} \mathrm{C}\right]$ adenine incorporation into DNA occurred at I to $2 \mathrm{~h}$, while germination and dry weight increases were detected only after $3 \mathrm{~h}$. We repeatedly found that there was a pattern of incorporation, with maximum values occurring at regular intervals of about $65 \mathrm{~min}$. In Fig. 3 these maximum values were located at $3 \mathrm{~h}, 4 \mathrm{~h}, 5 \mathrm{~h} 20 \mathrm{~min}, 6 \mathrm{~h} 20 \mathrm{~min}, 7 \mathrm{~h}, 8 \mathrm{~h} 10 \mathrm{~min}$, and $9 \mathrm{~h} 10 \mathrm{~min}$. Although the same average value of $65 \mathrm{~min}$ between maxima was determined for each separate experiment, the actual times at which the rates of $\left[{ }^{14} \mathrm{C}\right]$ adenine incorporation reached a maximum varied from experiment to experiment. This was because the first maximum value could occur at any time between 2 and $3 \mathrm{~h}$ after incubation commenced. 


\section{DISCUSSION}

The DNA contents of Fusarium oxysporum ( $\mathrm{I} \cdot \mathrm{I} 4$ and $0.95 \%$, respectively, for ungerminated conidia and mycelial pellets) are significantly higher than those reported in conidia of other species: $0.78 \%$ for Penicillium atrovenetum (Gottlieb \& Van Etten, 1964), $0.23 \%$ for Aspergillus nidulans (Bainbridge, I97I), and $0.26 \%$ for Fusarium solani (Cochrane et al. I97I). However, Maruyama \& Alexander (I962) found a DNA content of $2.6 \%$ in conidia of $F$. oxysporum f. sp. cubense. The lower values for mycelium are in agreement with many other results (Bainbridge, I97I; Gottlieb \& Van Etten, I964, I966; Maruyama \& Alexander, 1962). Probably more significant than the DNA content calculated on a dry weight basis is the DNA content per conidium; for $F$. oxysporum f.sp. melonis it has been calculated to be $0.134 \times 10^{-12} \mathrm{~g} /$ conidium, which agrees with the range of $0.02 \times 10^{-12}$ to $0.17 \times 10^{-12} \mathrm{~g} / \mathrm{cell}$ reported for fungal species (Sparrow, Price \& Underbrink, 1972). By using the conversion factor of $2.0 \mathrm{I} \times \mathrm{I}^{21}$ nucleotides/g DNA (Sparrow et al. 1972), an average number of $2.69 \times 10^{8}$ nucleotides/cell is arrived at for the ungerminated conidia. If the average gene size is estimated to be I 500 base pairs (Watson, 1965) it may tentatively be calculated that this is enough to code for at least 90000 genes. The value of $50.75 \%$ found for the $\% \mathrm{GC}$ of DNA agrees closely with Storck (1972), who found the GC content of the DNA isolated from several Fusarium species, to be within the range 50 to $55 \%$

The dry weight increases only slightly before germ-tube emergence in $F$. oxysporum, while for $A$. nidulans the increase in dry weight is reported to occur a long time before the germination of the conidia (Bainbridge, 1971). No synchrony was observed in germ-tube emergence but a partial synchrony was noticed in nuclear division, the proportion of hyphae with an even number of nuclei being always less than $65 \%$.

Partial synchrony is also suggested in DNA synthesis by the occurrence of a pause in the increase of DNA observed in several experiments. This pause occurred when the DNA per nucleus had exactly doubled and when the first nuclei began to divide. A slight synthesis of DNA was first detected after $3 \mathrm{~h}$ but increased sharply after $5 \mathrm{~h}$, and the highest content per nucleus was reached at $6 \mathrm{~h}$. The $\mathrm{S}$ phase therefore appears to last for only a short time. For A. nidulans, Kessel \& Rosenberger (1968) reported that the $\mathrm{S}$ phase lasted for $20 \mathrm{~min}$. The $\mathrm{G}_{2}$ phase, in the experiment reported in Table I and Fig. I, lasted for longer (nearly $2 \mathrm{~h}$ ); in other experiments not reported here it was briefer. Since the DNA content per nucleus in conidia during incubation is only slightly greater than that of the resting spore, it may be suggested that the GI phase is long as compared with the G2. This contrasts with the results of Williamson (I965) with yeast, where DNA synthesis started as soon as the buds appeared. The step-wise increase of the total DNA is compatible with the experiment using $\left[{ }^{14} \mathrm{C}\right]$ adenine pulse-labelling (Fig. 3) which also shows partial synchrony.

After 8 to $9 \mathrm{~h}$ the partial synchrony appeared to be lost. Different procedures, such as heat shocks, starvation and filtration, were tried to obtain a better synchrony, but the extent of synchrony of the treated population was little improved.

This work was partially supported by the Fonds National de la Recherche Scientifique (grant S 2/5-DG $5755 \mathrm{Z}$ ). L.K. is indebted to the Université Catholique de Louvain for a fellowship. We thank Dr B. W. Bainbridge for his comments on the manuscript and Mrs J. Weyns for technical assistance. 


\section{REFERENCES}

AIST, J. R. \& WiLson, C. L. (I965). Observations on nuclear division in vegetative hyphae of Ceratocystis fagacearum. Arkansas Academy of Sciences Proceedings 19, 32-36.

BAINBRIDGE, B. W. (197I). Macromolecular composition and nuclear division during spore germination in Aspergillus nidulans. Journal of General Microbiology 66, 319-325.

BrAY, G. A. (1960). A simple efficient liquid scintillator for counting aqueous solutions in a liquid scintillator counter. Analytical Chemistry I, 279-285.

Cochrane, J. C., Rado, T. A. \& Cochrane, V. W. (197I). Synthesis of macro-molecules and polyribosome formation in early stages of spore germination in Fusarium solani. Journal of General Microbiology $65,45-55$.

DE LEY, J. (1967). The quick approximation of DNA base composition from absorbancy ratios. Antonie van Leeuwenhoek 33, 203-208.

Erwin, D. C. (I973). Systemic fungicides: disease control, translocation and mode of action. Annual Review of Phytopathology Ir, 389-422.

GILES, K. W. \& MYers, A. (I965). An improved diphenylamine method for the estimation of DNA. Nature, London 206, 93.

Gottlieb, D. \& VAN EtTen, J. (1964). Biochemical changes during the growth of fungi. I. Nitrogen compounds and carbohydrate changes in Penicillium atrovenetum. Journal of Bacteriology 88, II4-I 2 I.

Gottlieb, D. \& Van Etten, J. (I966). Changes in fungi with age. I. Chemical composition of $R$. solani and $R$. bataticola. Journal of Bacteriology 9r, $\mathrm{I} 6 \mathrm{I}-\mathrm{I} 68$.

Gottlieb, D. \& Tripathi, R. K. (I968). The physiology of swelling phase of spore germination in Penicillium atrovenetum. Mycologia 60, 571-590.

Grivell, A. R. \& JACKSON, J. F. (I968). Thymidine kinase: evidence for its absence from Neurospora crassa and some other micro-organisms, and the relevance of this to the specific labelling of deoxyribonucleic acid. Journal of General Microbiology 54, 307-3I 7.

Hollomon, D. W. (I970). Ribonucleic acid synthesis during fungal spore germination. Journal of General Microbiology 62, 75-87.

Kessel, M. \& Rosenberger, R. F. (1968). Regulation and timing of DNA synthesis in hyphae of Aspergillus nidulans. Journal of Bacteriology 95, 2275-228I.

Krieg, R. E. \& Lockhart, W. R. (I970). Analysis of the thermal transition curves of DNA from microorganisms. Canadian Journal of Microbiology 16, 989-995.

MARMUR, J. (1961). A procedure for the isolation of DNA from microorganisms. Journal of Molecular Biology 3, 208-2 I 8.

Marmur, J. \& Doty, P. (1962). Determination of the base composition of DNA from its thermal denaturation temperature. Journal of Molecular Biology 5, I09-1 I 8.

MaruYAma, Y. \& AleXANDER, M. (1962). Distribution of protein and nucleic acids in hyphae and microconidia of Fusarium. Archiv fur Mikrobiologie 4I, 40I-407.

Munro, H. N. \& FleCK, A. (1966). Recent development in the measurement of nucleic acids in biological materials. Analyst 91, 78-88.

SiJPESTEIJN, A. K. (1970). Biochemical modes of action of agricultural fungicides. World Review of Pest Control 9, 85-93.

SisLer, H. D. (I968). Effects of fungicides on protein and nucleic acids synthesis. Annual Review of Phytopathology 7, 3I I-330.

Sparrow, A. H., Price, H. J. \& Underbrink, A. G. (1972). A survey of DNA content per cell and per chromosome of prokaryotic and eukaryotic organisms: some evolutionary considerations. Brookhaven Symposia in Biology 23, 45I-494.

Storck, R. (1972). Deoxyribonucleic acid of fungi. Brookhaven Symposia in Biology 23, 37I-393.

VAN DER KeRK, G. J. (1969). The development of synthetic fungicides: trends and prospects. Netherlands Journal of Plant Pathology 75, S I, 5-20.

Watson, J. D. (1965). The Molecular Biology of the Gene. First edition. New York: W. A. Benjamin.

Williamson, D. A. (1965). The timing of deoxyribonucleic acid synthesis in the cell cycle of Saccharomyces cerevisiae. Journal of Cell Biology 25, 517-528. 